\title{
It's Not About “Us”: Express Newark Prioritizing the Public Good
}

Victor Davson, Anne Schaper Englot, Chantal Fischzang, Tamara Fleming, and Nick Kline

\begin{abstract}
Publically engaged scholarship demands new ways of working within and outside of the academy.

Systems within the university reward faculty for individual achievements. This approach militates against working on collaborative projects because of the difficulty of explaining and quantifying one's contribution. The culture of academia further inhibits potential collaborations and undermines even the most altruistic faculty, who are socialized to devalue the experiential, place-based knowledge of a community partner and encouraged to adopt a self-concept as "the" authority.
\end{abstract}

But if universities are to honor their commitment to the public good, the public must be prioritized in the academic value system, which ought to encourage new modes of thinking that recognize the legitimacy of the expertise of community partners and place value on collaboration with them.

From the community perspective, there is often a lack of models for successful collaboration, with engagement by universities more often than not taking the form of exercising eminent domain or parachuting in to "fix" a problem and then abandoning the community. Community members carry with them skepticism that the university's only use is as a source of hand-outs rather than a source of the kind of agency afforded by true collaboration.

Keywords: Community engagement; arts and culture; faculty roles and rewards; anchor institution; social design; third space

\section{Introduction}

In this article, we examine two questions: first, what role can university leaders play in supporting faculty who are interested in publicly engaged scholarship and building trusting relationships with community members? Secondly, what role can university leaders play in supporting community members who are interested in publicly engaged scholarship and building trusting relationships with faculty?

In examining how Express Newark came into being and how it weaves into each of our stories, we hope to provide insight and offer alternative perspectives on seeding a college culture of social practice and social justice through the arts in an authentic university-community collaboration. Our work each day involves breaking down resistance to culture change; creating comfort with collaboration; and building a structure within and without the university that supports these goals. 
Each of the authors, Anne Schaper Englot, Victor Davson, Nick Kline, Tamara Fleming, and Chantal Fischzang, play an integral role in the telling of this story. Schaper Englot, the university co-director of Express Newark, sets up the what, where, how, when of the project. Davson, the community co-director of Express Newark situates the project within its historical context of the university/community relationship. Kline describes his practice as an artist and how he worked to achieve tenure as construction of Express Newark and his project the Shine Portrait Studio was nearing completion. He describes how, as a young assistant professor, he was told not to pursue a social practice because it could not be quantified on Form B. Fleming, a community partner in Shine Portrait Studio, describes her experience shaping Shine with Nick, and their collaborators and community partners, Colleen Gutwein and Tinetta Bell; and Fischzang describes the changing tide at Rutgers University-Newark where her journey towards tenure and promotion takes place within a changing environment, where the institution recognizes the value of engaged scholarship. This change affords her the latitude to create a fluidity between her teaching, her design practice, and her work in the community.

This is not to say that publicly engaged scholarship is not a risk for a young professor. While the promises have long been promoted by the likes of eminent scholars such as the late Ernest Boyer, the perils are also equally well-documented by committed scholars such as Sarena D. Seifer, Kristine Wong, Sherril B. Gelmon, and Miriam Lederer, who wrote that “...faculty roles are changing, but the faculty promotion and tenure system has not kept pace. For a number of reasons, promotion and tenure issues are a significant barrier to the full range of communityengaged scholarship (CES) in which faculty link their research, teaching, and service with communities (Bialek 2000; Nyden·2003; Institute of Medicine 1995; Gelman and AgreKippenhan 2002; Seifer 2003; Huber 1999).

\section{Express Newark, A Third Space-Schaper Englot}

Express Newark is a third space - an arts center and incubator, where the university and the community come together with equal voice. We begin the story here, because without an understanding of the term "third space", and the framework it provides, the story would be incomplete. A third space is best described as a space "... of interaction, where established and often unequal relationships of power and expertise can be shifted to acknowledge what each member of the partnership brings to the table” (Cantor, Englot, P., Higgins, 2013). The foundational concept was to co-create Express Newark with artists and arts organizations in Newark so that ownership was truly shared.

Third Space theory originated in the work of Homi Bhaba, and developed further in the work of other post colonialists and cultural geographers such as Paul Routledge. It delineates the native's first or home space and the colonizer's imported second space. Third space is a kind of hybridconsciousness where the colonized can retain aspects of native/first self, while assimilating the useful technology of the second space. Bhaba's primary concern is the articulation of this concept, and its manifestation in text. Routledge, on the other hand uses the third space as a guide to applied research in the form of activism or publicly engaged scholarship. 
We recognize Bhaba's original proposition and take as our project the exploration of the third space's potential to open the doors of the university, when codified in physical space. These two approaches may be understood in terms of a theory/praxis distinction. The distinction grows deeper in the work of our colleague Paul Jargowsky, who has written about the architecture of segregation (Jargowsky, 2018). Similarly, the work of Susan Sturm, who has written about the architecture of inclusion (Sturm, 2006), inspires her readers to move beyond a conceptual or geographic definition of third space, and to imagine how to break down brick and mortar barriers to the equal access. The importance of this work cannot be emphasized enough, when every day brings to light new scholarship that uncovers the depth of structural racism in America (Rothstein, 2017). Urban public universities cannot fulfill our public mission unless we learn to invite in all our citizens and learn from their experience. We must share our cultural resources, grow from the meeting of our minds and hearts, and provide access to higher education so that we can work alongside people in our cities.

We believe that in order to create lasting change, we need to enact what Nancy Cantor and Peter Englot have called for: building "real civil infrastructure" in order to "build long lasting collaborations and trust...key to promoting the social infrastructure collaboration that came from commitment to shared space and discussion." This necessarily involves "faculty and students but, just as importantly, professional staff nurturing this ecosystem and keeping it going by feeding new people into new projects all the time.” (Cantor, N., and Englot, P. 2015, p.77)

Therefore, architectural space is not just a catalyst, but it is essential to enacting the third space. This is what we have defined as creative placemaking, with academic artists in dialogue with Newark artists and community partners trying to think through the process of how to create a literal third space, an architectural third space.

Now that Express Newark is open, we are focused not just on opening the academic project to accommodate our activist agenda, but on creating a radical paradigm where the process of disruption is in fact the project. We bring (what the academy would consider) outsider knowledge in so that we can benefit from a wide-angle lens on the work, which is to question, present, and represent the world. In other words, we are interested in the disruption of the traditional academic project in order to effect transformational change. In our art/knowledge production, we must continually rethink systems, so that the art/knowledge collaboration we create keeps the third space at the center. The process is in fact the goal, not just a vehicle for enacting artwork or scholarship.

Bringing Express Newark back to Bhaba, university and community members engage in the messy project of collaboration, engaging in difficult dialogues, expressing our different knowledge and histories. We are not likely to reinforce each other's assumptions, so our perspectives broaden and our knowledge becomes enriched. In so doing, we subvert the presentation, reification and dissemination of theoretical (read colonial) art/knowledge to create a more democratic society.

The faculty and staff of Rutgers University-Newark built a tradition of engaged scholarship over decades of work in the city. In fact, this was one of the things that attracted Nancy Cantor to accept the position of Chancellor in 2014. Thus, it was not surprising when the Strategic 
Planning process - which was highly consultative including visits to each department, town halls, charrette groups comprised of faculty, staff, alumni, students, and community membersyielded a goal of being a university that was of Newark, not just in Newark. Over and over again, the notion arose that the university could not fulfill its public mission if it remained cut off from its city. While it was important to acknowledge and build on successful engagement work, there was still much effort needed to break down remaining barriers, especially those that were created during the unrest of the 1960s (more on that later).

For our story, two key interactions occurred during the listening tour. Chancellor Cantor was presented with a plan by the interdisciplinary department of Arts, Culture and Media (ACM) to create a space in downtown Newark to house their social practice. The initial proposal was envisioned by three people. Professor Nick Kline, a photographer interested in portraiture had partnered with local photographers to embed students in the community as social agents who worked with Newark residents to create self-representations of their unique stories. The university's Paul Robeson Art Galleries under the leadership of Anonda Bell, Chief Curator and Director, had the employment of Newark artists a core commitment. Not only did the gallery have a tradition of showing local artists, but they also trained local artists to be artist educators who were paid to design programs and workshops based on the gallery exhibits, which were delivered to diverse audiences of school children, senior citizens, the differently abled and offsite for the incarcerated. Finally, Ned Drew, Professor of Graphic Design led a project called the Design Consortium, where faculty and students worked together in a design studio to realize branding and graphic identity for not-for-profits in the city. The proposal imagined a space for engagement outside the Ivory tower of Bradley Hall, where the arts were housed, the space would be in the downtown - where engaged scholarship, where their social practice could live.

Concurrently, Chancellor Cantor and her team were consulting the important Anchor Institutions in Newark. Prudential Corporation - an Anchor founded over 150 years ago which had stayed in the city of Newark when other companies were fleeing to the suburbs-approached the university with a proposal for Rutgers-Newark to be a partner in the redevelopment of the Hahne \& Company building. Hahne's was a turn-of-the-century department store, which had been boarded up with plywood for over thirty years. Many attempts had been made over the years to redevelop the beautiful brick and limestone structure, but finally the right team was in charge, and with the signing of Whole Foods as the first anchor tenant, the project was poised to become a multipurpose building with retail and commercial tenants as well as 160 apartments at both market and affordable rates. In order to balance the equation, another anchor tenant was needed before the banks would release the next round of funding.

Schaper Englot came to RU-N as what is known in the academy by the unflattering term: a "trailing spouse.” Previously, she had achieved the rank of full professor in the State University of New York, at a small Ag \& Tech college where she taught for 18 years and served as a department chair and elected faculty leader. She landed in Rutgers-Newark's ACM department to teach Architectural History in the Art History program, initially as a tenure track a professor without tenure, but with the potential to apply for tenure. She started as a participant in the development of Express Newark, and ended as co-director owing to her professional background in architecture, her experience as an academic leader, including having developed several degree programs and overseen the construction of an academic building, and the administration's 
confidence in her understanding of the goals of enhancing engaged scholarship embedded in the Strategic Plan. This has come at a cost, however, as she has had to set aside a book project that is important for tenure, so the dean recommended her appointment be changed to a professor of practice where the co-directorship is her area of practice.

Express Newark, a university-community collaboratory, was born. The project hired architects, who completed a visioning document in August of 2014. The university's Strategic Plan includes a summary of this vision. It was unveiled in September, then in October Chancellor Cantor presented the plan and the Visioning Document to the Board of Governors. The Board of Governors approved \$25 Million in capital funds for the development of Express Newark and the rest is history. It is safe to say that never in the history of the university has any project proceeded with such expediency. The "express" in Express Newark is not meant to connote "fast" but rather the idea of the city expressing its soul, but in terms of the speed with which the project was realized, it is apt.

Express Newark is one of the key initiatives undertaken by RU-N as Anchor Institution work in the Arts and Culture and it is embedded in the Strategic Plan. It was made possible because the university allocated resources to support a rich educational experience for students, to support faculty and staff that have been engaging the community as part of their practice, and to support the city's arts ecosystem. Why this important, why is it needed? In order to answer these questions, we need to step back and examine the context dating back to 1960s when Newark became a majority Black city—-the architecture of exclusion was palatable.

\section{Contextualizing the University-Community Relationship—Davson}

Though the university's administration had overtly stated that the campus was a public space and everyone from the neighborhood was welcome, it is hard to imagine that local residents actually felt that way. Everyone agrees from the outset the University's architecture was not conceived with the surrounding community in mind. Below the observation deck that once connected Conklin and Boyden Halls at the entrance to the new campus, for example, one can see the darkened passageway that ushers the visitor from the street, up the stairs, to a place of light and higher learning. Instead there existed a real psychological—and physical—gate, enforced by police, then from the late 1970s, through campus security. (Giloi, E., personal communication, October 7, 2017)

Davson joined the Express Newark team as a consultant. He is an artist and the founding director of the locally and nationally celebrated center for contemporary art, Aljira, which he had run for over thirty years. In that time, he developed his skills in organizational development and management through participation in many well-known training programs, including the Executive Education Program at the Getty Center. Davson set the standard for leaders of small to midsize arts organizations in the City. He also witnessed the evolving relationship between Rutgers University-Newark and the surrounding community.

Like Rutgers University-Newark, the primary concern of the city's anchor institutions tended to be oriented towards their own rather than the community's interests. Davson recalls an anecdote where Sam Miller, a revered past Director of the Newark Museum, famously said, "The Newark 
Museum is a great museum-it's a pity it's in Newark”. Throughout the 60s, 70s, 80s and 90s the attitude of the Rutgers University-Newark arts faculty in the Newark arts scene remained ambivalent at best. They came to Newark to teach and then returned to their practice in New York. They viewed the local scene as parochial and were in turn viewed with suspicion by Newarkers. One exception was the Director of the Paul Robeson Gallery, Alison Weld, a predecessor of Anonda Bell. Ms. Weld curated a show of Davson's work in 1988 along with the work of artists Mel Edwards, Bill Traylor, and Norman Lewis. Notwithstanding such isolated conciliatory gestures, the university remained, essentially, inwardly focused and hostile, especially towards Black men.

This is not a surprise, considering that the university seemed not at all concerned about Blacks (nor the Puerto-Ricans/Hispanics and Portuguese for that matter) who made up $85 \%$ of the Central Ward where the Newark campus was built. At that time, Blacks were definitely the largest demographic in Newark, making up 34\% of Newark’s population. Italians and Jews were around $20 \%$ of Newark's population at that time but they did not live in the Central Ward "...the University really had its eyes on other demographics, and not at all on Blacks living in the neighborhood that was used for the campus." In 1967, only 1\% of the student body (across all three Rutgers campuses) was Black. The low enrollment of Blacks created a sense of mounting frustration in the community and on campus. In 1969 the situation came to a head with the takeover of Conklin Hall by RU-N’s Black Organization of Students. The administration resolved to do better and as a result, but in 1969, that number had risen only to 3\%. Small but significant gains, including the hiring of Black faculty, continued. (Giloi, E., personal communication, October 7, 2017)

Today the student body is among the most diverse in the nation (U.S. News and World Report, 2017), with Black students numbering around 18\%. The progress is real. However, with $35 \%$ of the population still living below the poverty line, and the college attainment rate at close to 18\% the city is still very much in recovery mode from the 60s. Many Newark residents have yet to benefit from the current renaissance in development of projects, such as the Hahne \& Company building. Davson sees Express Newark as a direct response to this history of exclusion, and as a countermeasure that puts university resources to the purpose of the community.

\section{Practice, Presentation and Perception-Kline}

At the 2007 CUMU conference Nick Kline's presentation included a digital montage of a portrait photography studio occupying an empty storefront in Newark, NJ. Shown for the first time, this was to be the cover image of a proposal to the Rutgers University-Newark administration, PS Newark. Portrait Studio Newark proposed a pop-up photography studio that brought students, off-campus, into deeper engagement with people in the city. Kline didn't know that during his presentation, Rutgers Provost Steven Diner was in attendance, and afterward offered a storefront space that the university owned as a possible site for the project. As it turned out there were three empty storefronts available, so Kline initiated relationships with the director of the campus art gallery and a professor of graphic design for site-specific projects. While these proposals never took off at this location, they became a foundation of Express Newark. 
Kline's practice as an artist includes photography, installation, artists' books, and socially engaged art. As Michael Henderson points out, 'Under a variety of names, 'social sculpture,' 'socially engaged art,' 'collaborative arts,' 'new genre public art,' or 'social practice,' has become a prominent form in the twenty-first century.” (Henderson, p. 98) Kline’s art practice builds on artists work, such as Joseph Beuys, the German artist who “...developed a theory of social sculpture, "centered on the belief that the concept of art could include the entire 'process of living' - thoughts, actions, dialogue, as well as objects-and therefore could be enacted by a wide range of people beyond artists” (Jordan, 2013, p. 145 quoted in Henderson, p. 98)

Kline's work is rooted in portraiture that bears witness to the spirit of place, people and trauma. It addresses the personal and communal impact of loss and the power of resilience. Kline's work in portraiture is both literal and conceptual, some of it is exhibited in art galleries while other works are utilized as advocacy in human service contexts, or in educational settings such as public libraries. His extensive and productive practice and significant exhibit record, comprised the portfolio needed for Kline to achieve tenure last year. He was among the group of academics across the country who had to achieve tenure despite, not because of his engaged artistic practice/scholarship.

This is not surprising as Tim Eatman and Julie Ellison, leaders of Imagining America, Artists and Scholars in Public Life, found when they studied this issue in 2008. Eatman and Ellison state: “...tenure and promotion policies lag behind public scholarly and creative work and discourage faculty from doing it. Disturbingly, our interviews revealed a strong sense that pursuing academic public engagement is viewed as an unorthodox and risky early career option for faculty of color.” (Eatman, Ellison, p. iv). For these reasons, their groundbreaking study, and the recommendations they provide, have become a road map for working toward creating tenure and promotion policies that will fairly value engaged scholarship and social practice.

Further analysis has been undertaken by a variety of groups including the Coalition for Urban and Metropolitan Universities which in 2016 devoted an entire issue of Metropolitan Universities Journal. Of particular relevance is Claire Cavallaro’s “Recognizing Engaged Scholarship in Faculty Reward Structures: Challenges and Progress" which begins with Boyer, and builds upon Eatman and Ellison then draws upon subsequent work by Saltmarsh, Sandmann, Giles and others to describe the present landscape. Also of interest is Lisa Krissoff Boehm and Linda S. Larrivee's article on mentoring junior faculty. There, the authors discuss the key role played by deans at their university who are deeply connected to the community and can therefore facilitating and encourage this work.

Embedded reappointment, tenure and promotion policies that facilitate and encourage publicly engaged work have been established at a number of institutions including Syracuse University. At Rutgers University-Newark, the work has begun. Solicited by the Deans offices, each department has convened working groups that have defined quality engaged scholarship and social practice and have listed criteria so that it can be recognized. These definitions and criteria are under review by the appropriate university committee. This is the first step toward creating policy that we hope will become institutionalized. In addition, a new office of Pedagogy, Professional Development and Publicly Engaged Scholarship (P3) has been created to support graduate student and faculty development. This work will only continue as initiatives like P3 and 
the Honors Living and Learning Community (HLLC) develop further. This last is a residential community focused on "Local Citizenship in a Global World” whose inaugural Dean is Tim Eatman.

Kline is deeply connected to the work of HLLC and P3 and co-taught courses under its rubric based on his artwork in which he investigates odd or unexpected subjects such as: (a) a photography series of people sleeping in their cars; or (b) the prevalence of men wearing striped shirts in disaster scenes as depicted by photojournalists; (c) an installation in which he striped an entire former church by flipping over sets of white boards, revealing the brown cedar color underneath; or (d) a collaborative project of books made of glass. The work guides the viewer to reconcile seemingly ordinary objects or situations with socially-charged contexts, and in doing so to engage that viewer in a conversation about difficult topics.

In some cases, like the Glassbook Project, or Shine Portrait Studio, Kline’s “hand” as the artist isn't present. With Shine, he collaboratively created a portrait photography studio based in downtown Newark, NJ, that reimagines the tradition of local "Main Street" studios as a new and hybrid educational and community- "owned” facility. Davson, accurately related Kline’s intentions for Shine when he stated: “This Portrait Studio builds on the legacy of an emancipated population empowered to construct its own identity and document its own history... and is rooted in the history of Newark and the struggle of the African American community to construct its own identity.” This project imagines a space that attempts to counteract the negative narratives told about Newark from the media and non-residents. It demands that Kline's artistic gesture is one of facilitation, creating structures of access, and deeply held cooperative spirit with the community.

In the field of contemporary art, social engagement is a common genre. It is embraced by many artists as a means of expression. In many cases, artists embrace it to be more direct in impacting change in the world. Some artists act from a sense of frustration that mere representation of political, social, and other injustices, in the photographic sense, is not adequate or urgent enough. Socially-Engaged Art is progressive, and frequently lives and functions within a public sphere or context that is far removed from the art gallery context. While embraced by the art world, Kline met resistance to this art form from within academia, while on a tenure-track. The message from a Dean was clear: pursue traditional gallery exhibitions, awards and critical reviews, and if this collaborative type work is submitted it wouldn't be considered for tenure. The standard Form 1$\mathrm{B}$ had not accommodation for this type of work. As a result, Kline pursued a dual track of both traditional exhibitions as well as engaged work.

During his tenure-track process, the Rutgers University-Newark administration changed and Kline found increasing support. Actually, there was an urgency for this type of work from the newly appointed Chancellor Nancy Cantor, who Kline credits for guiding his thinking toward equity and co-building with community partners. As such Kline's initial proposal shifted from the students doing for people in Newark, to creating a badly needed resource. At the core mission of Shine is a working portrait photography studio that facilitates and supports the expression and self-representation of the Newark, New Jersey community. It is a cutting-edge photography studio with state-of-the-art equipment and technical support free to use for Newark-based artists, photographers, stylists, fashion designers, entrepreneurs, and the entire creative community. 
Kline was awarded two course releases to run Shine, and he was allocated equipment and program funds to support the collective work he and his community partners were undertaking.

\section{Community Partnership Development_Fleming}

Tamara Fleming is a long-time resident and small business owner in Newark. She is a portrait and lifestyle photographer for corporations, non-profits and small business owners. She prides herself in providing real and relevant images that companies need to reach their target audience. In 2007, under a company she co-founded called FirstEye MediaWorks (dba FEMWORKS), she launched her business in the heart of Newark NJ and spent many years working with the community to create an impact and change the perception of the city.

Fleming works with women and young girls, using the camera as a vehicle to work through areas such as self-esteem, body image, self-confidence including a focus on community. Her program, ExpozHER: Personal Development Through Photography, has been implemented in Africa and Haiti, immediately following the 2010 earthquake which killed over 200,000. She has also for many years captured visual stories of the LGBT community. One exhibit, entitled "Newark Leaders: The LGBTIQ Portrait Project” was launched during the kick-off of Rutgers "Queer Newark Oral History Project” in 2012. The exhibit was a way to see and hear the struggles, passions and unwavering commitment of the LGBTIQ community in Newark. A featured participant of the exhibit, Rodney Gilbert, founder of Yendor Productions, was quoted saying "It wasn't initially through my sexuality, but my experiences as an African-American male that subconsciously affected me as I discovered coping mechanisms to build my self-esteem. In my adult years, those experiences regarding race in America and abroad became parallel with my sexuality.” (Gilbert, R., November, 2012)

During the presentation at CUMU, Fleming shared a story of her donating her services to support a local organization. In the presentation, she showed a slide featuring a behind-the-scenes clip of a recent photo shoot. Fleming was contacted by a Newark-based non-profit called "Eyes Like Mine”. This non-profit provides services to individuals who are visually impaired. The organization's founder needed professional photos to support the marketing and branding of its annual event, "Dancing with the Blind". In the behind-the-scenes (BTS) clip, the Mayor of Newark (who performed in the show), was captured practicing his dance moves with his dance partner during the photo shoot.

Fleming, along with Colleen Gutwein and Tinetta Bell, were all hand-picked, highly recommended community partners who worked with Nick Kline to shape the space and programming for Shine over the course of more than a year. In frequent meetings around the development of Shine, they discussed the program's purpose and how it supports the Chancellor's Strategic Plan. Community partners are in place to ensure that the Newark community will reap the benefits of having a state-of-the-art studio in its backyard.

During the planning session, wearing hard hats while walking through the shell of this historic building, the group would share options, thoughts and concerns about the development, knowing that their viewpoint would be heard and considered. 
The building is complete. Already a great many powerful collaborations and projects have been created by artists who use the space for both professional, personal and artistic goals.

Community partners and the public have access to space, equipment and technical support, as well as access to a growing network of artists, who range from the novice to the expert. The community partners are confident that upcoming programming will inspire the community and bring new artists into the spectrum. To date, Shine has hosted a multitude of artists. Newark fashion designer, Marco Hall has held photo shoots in the studio to the photography. Dr. Deborah Willis has curated a major photography exhibit of deeply engaged work.

Fleming feels her work \& contribution as a community partner will provide better opportunities for building authentic and sustainable relationships with the community and the university.

\section{Practice + Teaching + Service $=$ Scholarship - Fischzang}

Like Kline \& Fleming, through her teaching practice at Rutgers University-Newark and especially in Express Newark, Chantal Fischzang has been able to pursue co-building and social engagement through her practice and teaching. She arrived at RU-N in the Fall of 2012, right after completing her masters at Pratt Institute in Communications Design. First hired as a nontenure track assistant professor, after her first review, she transitioned to the tenure track and she anticipates applying for tenure in 2022. She focused her thesis on ways to define the design practice through a social lens; a new approach to design-social design.

Social Design, as Fischzang describes it, breeds a new type of designer; one who functions with aptitudes formulated beyond formal training. It can be better understood as an approach to life. Former AIGA \& Winterhouse Institute president William Drenttel, in his forward for Andrew Shea's Designing for Social Change, describes the activity as "inherently pragmatic and resultsoriented, simultaneously humble and ambitious, and fundamentally optimistic and forwardlooking.” (Shea, Drenttel, p. 06-07).

Andrew Blauvelt, former Director of Graduate Studies and Chair of the Graphic Design Department at the College of Design in North Carolina State University, explains the concept further, in his article “Towards Relational Design,” published in the Design Observer. The designer of today must become an enabler and catalyst of action/experience/thinking/feeling inspiring action through open-ended platforms of participation. He also acknowledges that the audience member (of today), in turn, is "a social being, one who is exhaustively data-mined and geo-demographically profiled," (Blauvelt, 2008) and is the vessel, as Fischzang concludes, that should guide our problem-solving process and solution seeking direction.

In the years since the completion of her thesis, Chantal Fischzang continued to dedicate her work to the notion of social design, involving her clients, audiences, partners \& students, into cobuilding design solutions in both her professional practice and her academic career at RU-N. She integrated Human-Centered Design (HCD) principles into her practice and teaching. HCD is a holistic approach that infuses the design process with both empirical and empathic research, untraditional field-work, and experimentation to understand people’s behaviors. 
The HCD model is predominately employed and put forward by Stanford University's d.school, and adapted into a business model called Design Thinking, by professor David M. Kelley,founder of the prominent design consultancy firm IDEO. It allows designers to articulate the problem as well as a solution, through combining creative principles with sociological fundamentals, in order to design deliverables that satisfy a people-first work ethic.

The mission of Design Thinking, as expressed by Kelley’s partner and IDEO’s CEO Tim Brown in his book Change by Design, is "to translate observations into insights and insights into products and services that will improve lives.” (Brown, p. 49)

Through this type of practice Fischzang has engaged in projects that improved her designmaking and education practice. Not only did these projects raise public awareness of social justice and environmental responsibility through design, but through the projects she has strategically explored the way those topics, values and methods can be applied in her classroom.

Practice

One of the most important aspects of Fischzang's professional development has been the collaborative process. Human-centered design processes tend to be more effective when corroborated by a collaborative dialogue. This linkage between socially engaged design and collaborative practice has become more and more relevant in recent years. Bruce Mau, a key innovator in the realm for social change through design, has stated in his book Massive Change, that "design is the human capacity to plan and produce desired outcomes." That planning and production of outcomes is better founded and more democratic when it is informed by a collaborative and/or participatory process with the audience.

He also states that collaboration is necessary because "the space between people working together is filled with conflict, friction, strife, exhilaration, delight, and vast creative potential." Highly charged social issues are best addressed in design through a process of thoughtful exchange among designers and experts from other fields. Cited by Stephen J. Eskilson in his book Graphic Design, A New History, in a section about the new "Citizen Designer," Mau proposes "a new commitment to cross-pollination and collaboration..." (Eskilson, p. 417), as a model for cultural transformation.

Collaborative design practice with a human-centered approach is how Fischzang defines her journey towards tenure and promotion.

For the past five years, Fischzang's work has been mostly collaborative. Fischzang is co-founder of IntraCollaborative (Intra), a partnership of 5 practicing designers and educator that came together based on a strongly shared belief in design as an agent of change and they continually look for ways to extend the principles of their academic pursuits into local environments and communities, working jointly to unravel complex issues and develop design materials aimed at social education and reform.

With Intra, she has worked on various publicly funded and pro bono projects around NYC. Through this work, as well as part of other collaborations, Fischzang has received various design 
awards, grants and has exhibited her work at the Cooper Hewitt Smithsonian design museum.

Practice + Teaching + Service

At RU-N, Fischzang found a clear intersection and productive exchange between her career focus, her role in the classroom and her service to the community, through service learning. Therefore, she continued to investigate ways in which social contexts can be applied to the fundamentals of graphic design: image, word and message-making through different mediums. In class, as it is in the practice of design, the process is as important as the final solution.

Fischzang asks her students to stress the relevance of how their process has allowed them to discover what the result is going to be as opposed to working towards a pre-established outcome. Ultimately, this prepares students to find a way to align their future clients' goals with their own responsibility towards the audience.

In 2007, Katherine McCoy, co-chair of the graduate Design program for Cranbrook Academy of Art, and best known as one of the apostles of Postmodernism and New Wave in communications design, was also cited by Eskilson in his Citizen Designer segment. She condemns the fact that many design programs have trained students to suppose that "political and social concerns are either extraneous to our work, or inappropriate.” In her essay Rethinking Modernism, Revising Functionalism, she further points out that "deeper concerns" that shape her design work and philosophy, are "the audience's interpretation and participation in the construction of meaning." (McCoy, p. 49)

Encouragingly for Fischzang, her experience bringing in these concepts, has been well-received at RU-N's Arts, Culture and Media Department, where Fischzang's teaching has served as a platform to apply her practice. Since her arrival, her intention has been to reshape design education by ensuring that students understand the significance of context in their work as well as the way formal, conceptual and theoretical aspects are applied.

Based on AIGA's Designer of 2025 report, design students must be prepared to consolidate the demands of multiple stakeholders, while assessing the impact of their work on socio-cultural environments. Emily Gosling, senior editor for AIGA's Eye on Design, writes "What that essentially boils down to is accountability: designers now more than ever need to justify their research and outcomes, and be aware of potential issues around representation, interpretation, and dissemination of products and images.” (Gosling, 2017)

Consequently, Fischzang has worked to define how social design proves to share an inherit connection between design practice, teaching, and community engagement. She has further explored this relationship by applying these notions to senior courses and the content for the student's BFA portfolio exhibition. Her system has involved design thinking as a methodology that focuses on a human-centered approach to design-making and empathy as a strategy for students to understand how people feel to move them through their work.

For instance, a student who was in the process of defining her capstone project- the content for her exhibition-was suffering from anxiety to the point where she was paralyzed and could not produce. She was visiting the Campus Counseling Center and they encouraged her to continue 
working without having to define the work. Fischzang and the student defined this process as "mindless making." Fischzang advised the student to make use of this experience and create promotional materials for the counseling center by employing the same approach/effect. As a result, the student created a campaign called Relief Project which involved a series of posters that engaged the audience into the physicality of the poster, to participate in the making of it and contribute to its meaning. As the audience (students) participating in threading, coloring and a tearing (reductive collage) of the posters, they actively covered the word "anxiety," and all that was left was the word "relief."

Practice plus Teaching plus Service equals Scholarship

Chantal Fischzang considers herself "a beneficiary of a new environment at RU-N that recognizes the value of this [publicly engaged] pursuit.” Professor Ned Drew, the Director of the Design program at the ACM department, and one of the spearheads of the initial conception of Express Newark, drew both Fischzang and their colleague, Jennifer Bernstein, assistant professor of design, into building a framework for service-learning Their partnership sought to create a program that could engage design students with the Newark community. Together they cofounded two partner programs at Express Newark: The Design Consortium \& Visual Means. These programs are part of the ACM department's Graphic Design curriculum. They are design courses that function as design studios where graphic design students, partake in real-world problems and offer design solutions for community organizations, researchers, activists and educational institutions in Newark and beyond.

The Design Consortium's inaugural project at Express Newark was the Express Newark identity system. This is a project exemplifies the complete dynamics of their collaborative process clients become their partners and students and faculty work together as a team.

The Express Newark branding process immersed the Design Consortium into four semesters of identity development, in which faculty took turns to tackle specific components of the project during each semester. Fischzang and Bernstein first offered a collaborative brainstorming workshop where all stakeholders (faculty, staff, students and community members) contributed to the initial concepts for the identity. The next phase involved establishing a visual concept through branding, led by Jennifer Bernstein. The following semester, Ned Drew's class refined the logomark concepts and extended them into a cohesive brand system including a robust brand guideline publication and an initial phase of the building's signage that was later fully addressed by Bernstein's second term in the process. Later, Fischzang led her class into applying the brand system into marketing extensions such as stationery, custom merchandize, communication materials, social media implementation and participatory executions, including elements for the EN opening that allowed for the public to engage in a reflection of the EN identity.

Fischzang and Kline were part of a faculty committee that wrote the criteria for tenure committees to review engaged scholarship. Fischzang will be the first faculty member in the ACM department to test this new definition. Through Express Newark, the university is embracing and defining community engaged scholarship by supporting faculty, like Kline and Fischzang, to make use of the arts to communicate with/for/about the community. 


\section{Conclusion}

In a very real sense, Express Newark is a fulfillment of the university's public mission. University leaders at Rutgers Universities-Newark have played an essential role in supporting faculty who are interested in publicly engaged scholarship through a number of key efforts. For the faculty in the arts the investment in building Express Newark at a site that was outside the footprint of the university, and in a public building, was perhaps the most definitive. In the addition to the custom-built space, the Chancellor's office funds an operating budget for the project which pays for programing and staffing. Members of the leadership team have partnered with faculty and community members in fundraising and grant writing. The Express Newark team is continually brought in to talk at important events with key stakeholders in education such as the Anchor Institution Task Force, donors, alumni, and the Middle States Commission. The Dean's office and the HR office have worked extensively with us to imagine structuring positions in a way that supports our work, and at the same time that works for community artists who work as teachings artists, preparators, and gallery attendants. The legal and procurement arms of the university have worked with us to imagine new forms of contracts that are appropriate for artist residencies of varying lengths. In this way, they are supporting community members who are interested in collaborating with faculty to produce publicly engaged scholarship and building trusting relationships with the university.

A key part of building trust between the university and the community was to hire a community codirector, a key step in assuring the community that the university was serious about creating equitable and meaningful partnerships. When Davson first joined the team, he was engaged to provide a reality check for the project. Specifically, he matched the goals with outcomes and perceptions. He was to write a report, which would culminate in a mission statement for Express Newark. Davson's report was undertaken with Bell and Schaper Englot assessing the capacity of local arts organizations who might be potential community partners in Express Newark. As the research for the report progressed it became clear that in order for Express Newark to be believed as a third space by the Newark arts community, the partnership would need to extend to the leadership. As co-director Davson has a direct impact on ensuring equity is more than an abstraction at Express Newark. One of the most significant aspects of the project is that the university is transferring wealth and agency and in doing so, shifting power to members of the community who understand how to most effectively deploy those resources. Davson has been hired for an extended period to serve as the co-director of Express Newark and is a true partner in personnel and programing decisions that shape the budget. Each and every day he and Schaper Englot engage in meeting with community artists, activists and organizations who wish to create programing and partnerships in Express Newark. They also meet with faculty and students to discuss future projects and the strategic direction of different initiatives. In a short period of time Express Newark has developed into a vital part of the arts ecosystem awarding sub-grants, honoraria, and stipends to artists-in-residence, employing artists as cultural workers teaching, curating, administering projects. Daily we collectively work to fulfill the promise of our mission statement.

Express Newark is a conceptual framework and an interdisciplinary learning space where artists and community residents collaborate, experiment, and innovate in partnership with Rutgers University-Newark faculty, staff, and students to engage in creative practice, foster democratic dialogue, and promote positive transformation. 


\section{References}

AIGA Educators, (2017, August 21). AIGA Designer 2025: Why design education should pay attention to trends. Retrieved from https://educators.aiga.org/wpcontent/uploads/2017/08/DESIGNER-2025-SUMMARY.pdf

Bhaba, H. (2006/3). Le tiers-espace: entretiens avec Jonathan Rutherford. Multitudes, 3(3) 95107. http://doi.org/10.3917/mult.026/0095

Blauvelt, A. (2008, March 3). Towards Relational Design. Design Observer. Retrieved from https://designobserver.com/feature/towards-relational-design/7557/

Boyte, H. (2009). Civic Agency and the Cult of the Expert. Dayton, Ohio: The Kettering Foundation.

Brown, Tim. (2009). Change by Design. New York, New York. Harper Business.

Cantor, N., Englot, P., \& Higgins, M. (2013). Making the Work of Anchor Institutions Stick: Building Coalitions and Collective Expertise. Journal of Higher Education Outreach and Engagement, 17(3), 17-46. Retrieved from http://openjournals.libs.uga.edu/index.php/jheoe/article/view/1036

Cavallaro, C. (2016). Recognizing engaged scholarship in faculty reward structures: Challenges and progress. Metropolitan Universities Journal 27 (2) p. 2-5. Retrieved from https://journals.iupui.edu/index.php/muj/article/view/21228 https://doi.org/10.18060/21122

Dewey, J. (1916). Democracy and Education: An Introduction to the Philosophy of Education. New York, New York: The MacMillan Company.

Eatman, T. K., \& Ellison, J. (2008). Scholarship in public: Knowledge creation and tenure policy in the engaged university a resource on promotion and tenure in the arts, humanities, and design. Imagining America: Artists and Scholars in Public Life Tenure Team Initiative on Public Scholarship. Retrieved from http://imaginingamerica.org/wpcontent/uploads/2015/07/ScholarshipinPublicKnowledge.pdf

Eskilson, S. (2007). Graphic Design: A New History. New Haven. Yale UP. p. 417.

Gilbert, R., (November, 2012). Personal communication with Tamara Fleming, November, 2012.

Giloi, E. (2017, October 7). Newark Rhythms project, personal communication with Victor Davson.

Giloi, E. (2018). Newark Rhythms. Newark: Express Newark Press. 
Gosling, E. (2017, October 25). What Will A Designer + Their Job Look Like in 2025? AIGA, Eye on Design. Retrieved from https://eyeondesign.aiga.org/what-will-a-design-job-in2025-look-like/

Gilbert, R., (November 2012). Personal communication with Tamara Fleming, November, 2012.

Giloi, E. (2017, October 7). Newark Rhythms project, personal communication with Victor Davson.

Giloi, E. (2018). Newark Rhythms. Newark: Express Newark Press.

Jargowsky, P. (2015). The Architecture of Segregation: Civil Unrest, the Concentration of Poverty, and Public Policy. Washington, D.C.: The Century Foundation.

Mau, B. (2004). Massive Change. London. Phaidon.

McCoy, K. (1994). Rethinking modernism, revising functionalism. In Bierut, M., Drenttel, W, Heller, S. \& Holland, D.K. (Eds.), (pp. 49-50). Looking closer: Critical writings on graphic design. New York: Allworth Press.

Rothstein, R. (2017). The Color of Law: A Forgotten History of How Our Government Segregated America. New York, New York: Liveright Publishing Corporation.

Routledge, P. (1996). “The Third Space as Critical Engagement,” Antipode, 28:4, p.399-419. https://doi.org/10.1111/j.1467-8330.1996.tb00533.x

Seifer, S.D., Wong, K., Gelmon, S.B., and Lederer, M. (2009). “The Community-Engaged Scholarship forHealth Collaborative: A National Change Initiative Focused on Faculty Roles and Rewards," Metropolitan Universities Journal, 20(2), 5-21.

Shea, A. Drenttel, W. (2012) Forward. Designing for Social Change. New York, New York. Princeton Architectural Press. pp. 6-7.

Sturm, S. (2006). The Architecture of Inclusion: Advancing Workplace Equity in Higher Education. Harvard Journal of Law and Gender, 29(2), 247-344. Retrieved from http://harvardjlg.com/wp-content/uploads/2012/01/sturm.pdf

U.S. News and World Report. (2017, September 11). Campus Ethnic Diversity-National Universities. Retrieved from https://www.usnews.com/best-colleges/rankings/nationaluniversities/campus-ethnic-diversity 


\section{Author Information}

Victor Davson, is Co-Director of Express Newark; Founding Director, Aljira, a Center for Contemporary Art. A graduate of Pratt Institute, Davson has had a successful decades long art practice and a thriving gallery which has contributed to the careers of many under-represented artists and curators including Frank Bowling, Carrie Moyer and Okwui Enwezor. Davson holds a BFA from Pratt Institute and has done advanced study at NYU and the Getty Center.

(victor.davson@rutgers.edu)

Chantal Fischzang is an Assistant Professor of Design at Rutgers University-Newark and a Director of the Design Consortium and Visual Means. Fischzang holds an MFA from Pratt Institute in Communications Design. (cf360@newark.rutgers.edu)

Tamara Fleming is a Photographer and a founding Community Partner of Shine Portrait Studio as well as an entrepreneur and owner of Tamara Fleming Photography she was also co-founder of FirstEye MediaWorks (dba FEMWORKS) a marketing communications firm in Newark, NJ. (info@tamaraflemingphotography.com)

Nick Kline is an Associate Professor of Photography at Rutgers University-Newark and is the founding Director of Shine Portrait Studio as well as an artist with an international exhibition record. Kline holds an MFA from Cranbrook Academy. (domkline@newark.rutgers.edu)

*Anne Schaper Englot is Co-Director of Express Newark and Professor of Practice of Architecture and Humanities at Rutgers University-Newark. Schaper Englot holds an M.Arch and Ph.D. from Syracuse University. (anne.englot@rutgers.edu)

All authors can be reached at this address:

Express Newark

54 Halsey St.

Newark, NJ 07102

848-445-0544

* Corresponding author 